\title{
The Chronostratigraphy of the Aurignacian in the Northern Carpathian Basin Based on New Chronometric/Archeological Data from Seňa I (Eastern Slovakia)
}

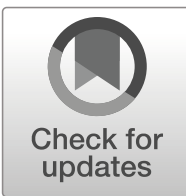

\author{
Wei Chu ${ }^{1}$ (D) L Lubomíra Kaminská ${ }^{2,3}$ • Nicole Klasen ${ }^{4}$ • Christian Zeeden ${ }^{5}$. \\ György Lengyel $^{6}$
}

Published online: 27 November 2019

(C) The Author(s) 2019

\begin{abstract}
The northern Carpathian Basin has important geological, paleoenvironmental, and archeological records that are key to our understanding of the first modern human occupation of Europe. However, the nature and timing of hominin settlements in the region during the Late Pleistocene remain poorly understood. New fieldwork at Seňa I, Slovakia, has identified the only known stratified open-air Aurignacian site in the region and assigned the assemblage to at least $33.5 \pm 2.4 \mathrm{ka}$ ago through infraredstimulated luminescence dating. Additionally, new archeological and geoscientific data are presented. This paper discusses the Seňa I findings in the context of the regional archeological record and shows how they contribute to the establishment of clear time constraints for the Aurignacian in eastern central Europe.
\end{abstract}

Keywords Early Upper Paleolithic · Aurignacian · Optically stimulated luminescence · Carpathian Basin

\section{Introduction}

Research over the last decade has improved our understanding of the European geological, environmental, and archeological records for the Late Pleistocene. The northern Carpathian Basin is an important region for this period as it forms part of a potential crossroad where Middle Paleolithic (e.g., Mousterian, Jankovician) and early Upper Paleolithic (e.g., Bohunician, Szeletian, Aurignacian, and Gravettian) technocomplexes are described (Chu 2018 and references therein).

Wei Chu

wchu@uni-koeln.de

Extended author information available on the last page of the article 
Despite increased research, the chronology of the Late Pleistocene archeological record of the northern Carpathian Basin remains poorly understood. In the Bükk Mountains, recent attempts to clarify the age estimates and cultural successions of the famous Szeleta, Istállós-kő, and Pes-kő caves have highlighted a scarcity of diagnostic artifacts, a poor understanding of stratigraphies, and difficulties in producing meaningful numerical chronologies (Bánesz 1989; Davies and Hedges 2008; Hauck et al. 2016; Lengyel and Mester 2008; Markó 2015; Patou-Mathis et al. 2016). In the surrounding landscape, open-air sites are known in and around the North Hungarian Range but are mostly unstratified, and secure radiometric ages are still unknown (Dobosi 1995, 2013; Kozłowski et al. 2009; Kozłowski et al. 2012; Lengyel et al. 2006; Markó et al. 2002). In nearby northwestern Romania (c. $175 \mathrm{~km}$ southeast), reexaminations of the sites of Boineşti, Buşag, Călineşti, and Remetea Şomoş I \& II suggest that, while there may be Aurignacian artifacts in the assemblages (Anghelinu and Niță 2014; Dobrescu 2008), they have been reworked with Mousterian and Gravettian elements and therefore cannot be confidently separated and dated (Tuffreau et al. 2013).

The situation is slightly better in eastern Slovakia along the Hornád Valley (Bánesz 1968; Hahn 1977; Kaminská 2014) where Aurignacian assemblages have been reportedly associated with deeply incised ditches interpreted as subterranean storage units or dwelling structures (Prošek 1953). Still, artifacts were recovered in short or unstratified sedimentary sequences and the three radiometric ages available from the sites of Košice-Barca I $(29.68 \pm 0.25$ ky (uncal) B.P.; GrA$16,157)$ and Kechnec I $(27.55 \pm 0.14$ ky (uncal) B.P.; OxA-15,678 and $27.37 \pm$ 0.21 ky (uncal) B.P.; GrA-24,329) have been questioned due to the long interval between excavation and dating that may have caused contamination (Kaminská 2014, p. 156; Verpoorte 2002).

Thus, the main goal of our work was to reexamine the Paleolithic record of the northern Carpathian Basin. Following test pitting at multiple sites (Chu et al. 2018), we present the results of a systematic excavation at the site of Seňa I that allowed us to obtain new lithic material, re-examine their stratigraphic context and acquire radiometric ages. Our results indicate the existence of the only known open-air stratified Aurignacian assemblage in the northern Carpathian Basin and establish an age consistent with chronological ages from the surrounding regions. This timing has implications for the regional modern humans' occupation of eastern central Europe.

\section{Background}

The site of Seňa I $(48.556307,21.254560 ; 196 \mathrm{~m}$ asl) is located in eastern Slovakia $3 \mathrm{~km}$ north from the Hungarian border at the boundary of the villages of Seña and Kechnec (Košice Region) on a terrace of the Hornád River. The site was discovered in 1951 and excavated in 1955 by L. Bánesz (1958, p. 195; 1989). The main excavation area $\left(45 \mathrm{~m}^{3}\right)$ was located in the northwestern corner of the Seňa cemetery where six clusters of Paleolithic artifacts were found (Fig. 1). Fifty meters further north on a gravel outcrop, an artifact bearing pit was also excavated. Bánesz noted a simple stratigraphy starting with a topsoil $(40-50 \mathrm{~cm})$, followed by a $20-30 \mathrm{~cm}$ layer of 

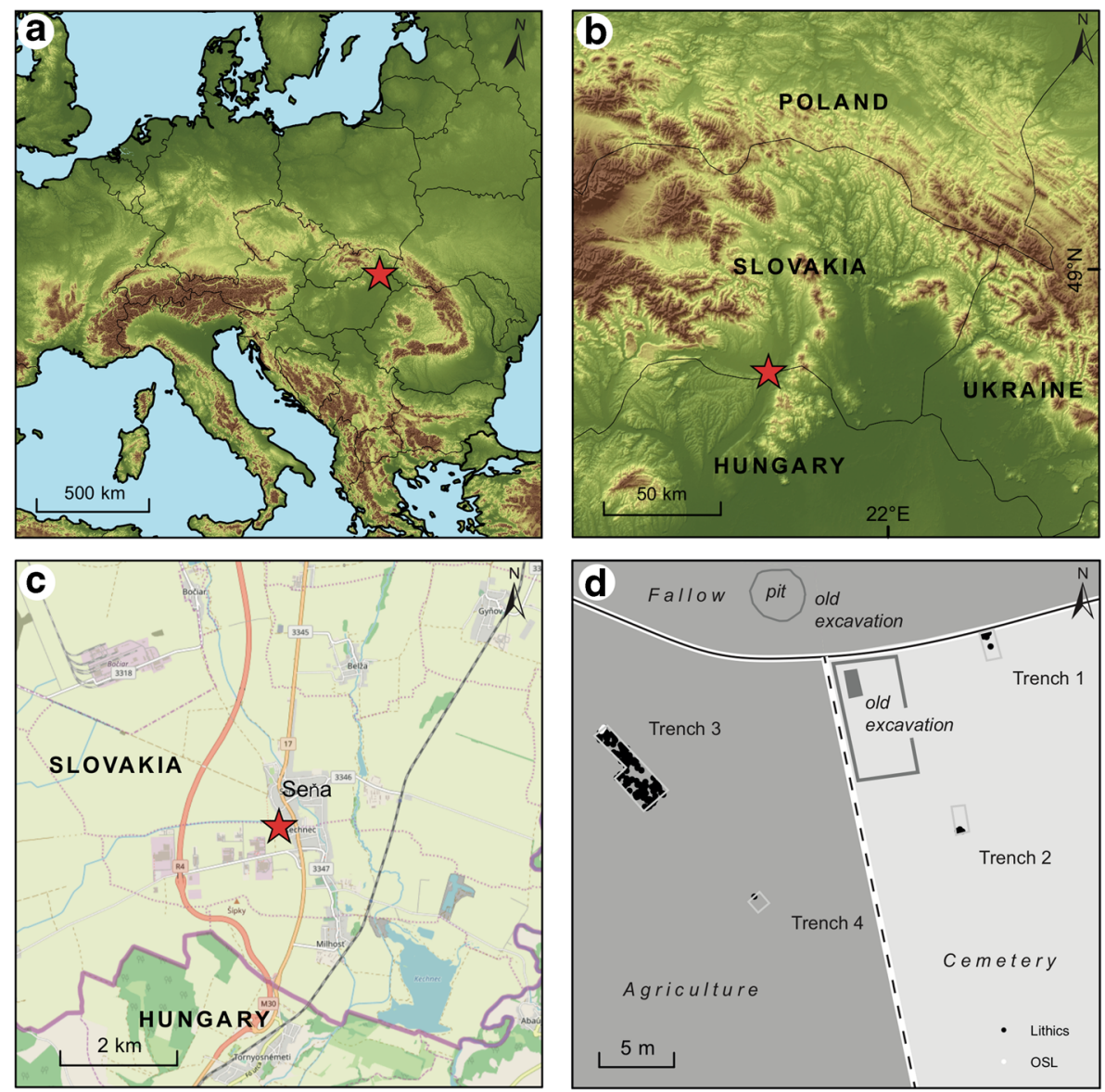

Fig. 1 Location of current excavations within a Europe, $\mathbf{b}$ eastern Slovakia, and $\mathbf{c}$ Seňa $\mathbf{d}$ the excavation area. Projection is latitude-longitude WGS84; DEM is SRTM

yellowish loess containing scattered cold-adapted malacofauna and charcoals. Archeological finds were located at the base of the yellowish loess at the interface with the underlying terrace gravels.

Lithic artifacts $(N=1211)$ were made from heavily patinated local limnosilicites (i.e., limnoquartzite), though radiolarite tools and worked silicified sandstones were also present (Kaminská 2013). Limnosilicites, radiolarite, and sandstone are mesolocal in origin (Slanské Hills; c. 25 km, Pieniny Klippen Belt; c. 65 km; Vihor Hills; c $80 \mathrm{~km}$, respectively) but are present in the riverbed near the site. Both cores and their associated knapping residues were recovered. Flake production predominated the assemblage (> 85\%; Bánesz 1956 p. 626), and the 51 tools were mostly endscrapers including three carinated forms. Bánesz ascribed the assemblage to the Middle Aurignacian. Hahn (1977) later suggested that it was Aurignacian, but only tentatively, due to the absence of clear fossiles directeurs due to the poor raw material quality and lack of faunal preservation (e.g., Dufour bladelets, strangled blades, bone points). 


\section{Methods}

\section{Excavation}

In July of 2016, four test trenches were installed surrounding the original Seňa I excavation site with the aims to examine the stratigraphy, obtain new archeological material, and produce radiometric ages (Fig. 1). Fifteen square meters were excavated in four trenches at $2 \mathrm{~cm}$ spits (that did not traverse geological horizons) to a depth of $85 \mathrm{~cm}$ (the top of the gravels). All objects above $5 \mathrm{~mm}$ were recorded with a total station and the collected sediments from quarter square meters of which $25 \%$ were wetsieved (1.2 mm mesh) for smaller artifacts. The subsequent lithic analyses focused on measuring artifacts (i.e., length, width, thickness, and weight) and describing features specific to known archeological cultures including technology and typology (sensu Demars 1992; Inizan and Féblot-Augustins 1999).

\section{Stratigraphy and Sedimentology}

The stratigraphy, texture, and sediment composition were recorded in the field. Grain size measurement was conducted using a laser diffraction particle size analyzer (Beckman Coulter LS 13320 PIDS) and by calculating the mean diameters of the grains within a range of 0.04-2000 $\mu \mathrm{m}$. Each sample was measured twice with two different concentrations of sediment in the solution to increase accuracy. Measurements with reliable obscuration (8-12\%) were averaged and are previously reported and discussed in Chu et al. (2018).

Here, end member modeling analysis (EMMA) of the entire set of the previously reported grain size data was performed using the EMMAgeo $\mathrm{R}$ package (Dietze et al. 2013; R core team 2018) to ascertain the sedimentary processes and post-depositional processes of the sediments. EMMA is a powerful and flexible multivariate statistical method used to identify and quantify sediment transport processes from multimodal grain size distributions. The grain size data used are available in the Pangaea database (Zeeden et al. 2016b).

\section{Age and Chronostratigraphy}

Three sediment samples, from which polymineral fine grains (4-11 $\mu \mathrm{m})$ were extracted for luminescence measurements, were collected at and above the main archeological finds between 60 and $85 \mathrm{~cm}$ depth below surface (Fig. 2) and were prepared for luminescence dating using standard techniques (Frechen et al. 1996). Measurements were carried out on an automated Risø TL/OSL DA 20 reader equipped with a calibrated ${ }^{90} \mathrm{Sr}$ beta source. Post infrared stimulation measured at $290{ }^{\circ} \mathrm{C}\left(\mathrm{pIRIR}_{290}\right.$, Thiel et al. 2011) was carried out with infrared diodes $(870 \mathrm{~nm}, \mathrm{FWHM}=40)$, and the signals were detected through an interference filter $(410 \mathrm{~nm}$; SIla-d). The initial $4 \mathrm{~s}$ of the signal minus a background of the last $20 \mathrm{~s}$ was used for $\mathrm{pIRIR}_{290}$ dating. Laboratory experiments included prior-IR stimulation temperature tests (Buylaert et al. 2012) using a range of temperatures from 50 to $220^{\circ} \mathrm{C}$ and dose recovery tests (SI2; SI3a-b). For this dose recovery test, samples were illuminated for $24 \mathrm{~h}$ in a Hönle SOL2 solar simulator, and a laboratory dose in the range of the natural dose was given to the 


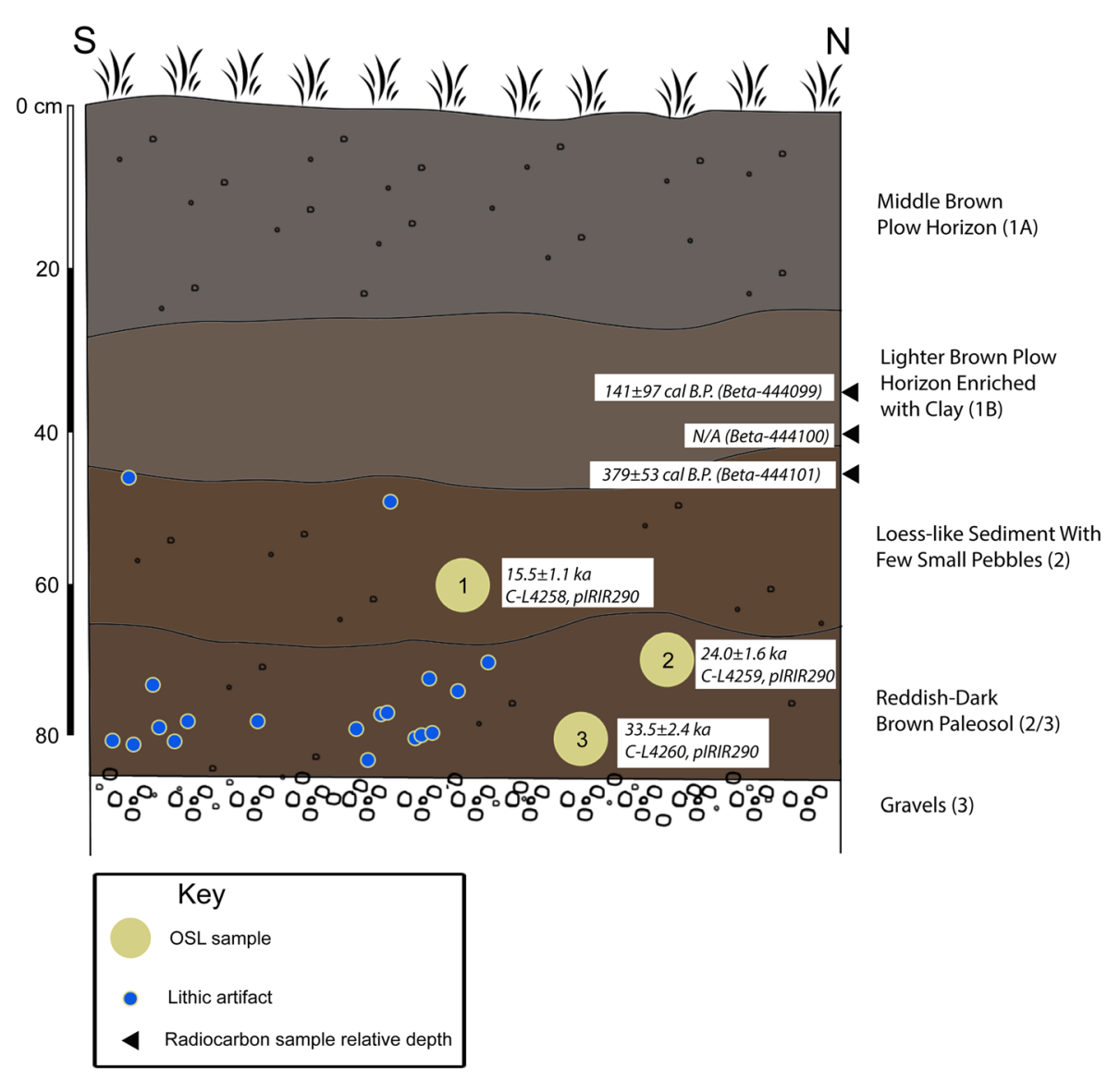

Fig. 2 Seňa I, Kechnec. a Geological section of trench 3 (square E1 northwestern wall) showing distribution of lithic artifacts, OSL samples ( 1 = C-L4258, 2 = C-L4259, and $3=$ C-L4260), and the lateral extent of unit 6

samples. Additionally, infrared stimulation measured at $50^{\circ}\left(\mathrm{IR}_{50}\right.$, Wallinga et al. 2000; Preusser 2003) was carried out for the three samples (SI1a-d). Equivalent doses were calculated with an arithmetic mean. Fading tests (Auclair et al. 2003) were carried out for all samples for the $\mathrm{IR}_{50}$ and the pIRIR 290 measurement protocols. Only the $\mathrm{IR}_{50}$ ages were corrected for fading following the approach of Huntley and Lamothe (2001). The environmental dose rate was measured using high-resolution gamma ray spectrometry. We have calculated the gamma dose rate for sample C-L4260 after Aitken (1985, Tab. H1) to allow for dose rate heterogeneity arising from the underlying gravels and by assuming that the gravels are inert. The environmental dose rate was calculated using the DRAC v.1.2 (Durcan et al. 2015) using conversion factors of Guérin et al. (2011), an $a$ value of $0.07 \pm 0.02\left(\mathrm{IR}_{50}\right.$, Preusser 2003) and $0.12 \pm 0.02(\mathrm{pIRIR} 290, \mathrm{Schmidt}$ et al. 2018) and the measured water content. The internal beta dose rate contribution of the polymineral fine grain samples was calculated by assuming a potassium content of $12.5 \pm 0.5 \%$ (Huntley and Baril 1997). Alpha and beta attenuation factors of Bell (1980) and Guérin et al. (2012) were used. The cosmic dose rate was calculated following Prescott and Hutton (1994). Results are presented in Table 1. 


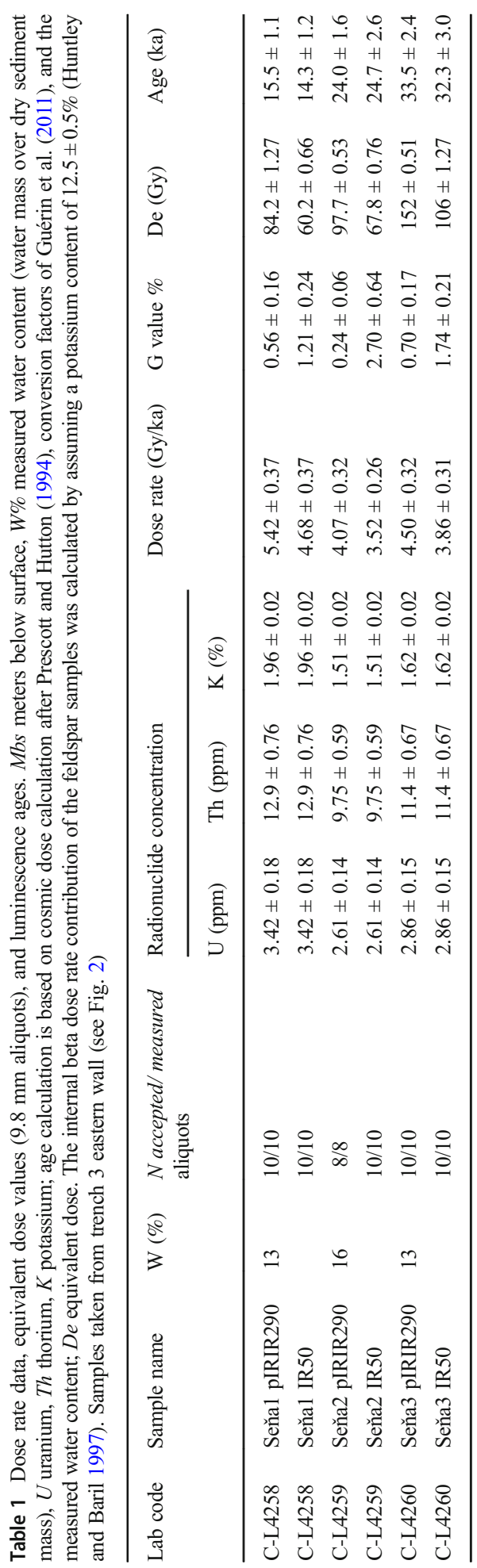


Additionally, AMS ${ }^{14} \mathrm{C}$ dating of three micro-charcoal (342-0.02 mg) samples found above the find level was carried out by BETA analytics, and the results using the INTCAL13 calibration curve (CalPal) are displayed in Table 2. Samples were pretreated by gentle crushing and dispersal in deionized water where they were then washed in hot acid $(\mathrm{HCl})$ then alkali $(\mathrm{NaOH})$ then acid solutions and dried.

\section{Results}

\section{Stratigraphy and Sedimentology}

There was considerable spatial variability of the preserved sediment cover in spite of the same geological succession. While trench 1 showed $\sim 50 \mathrm{~cm}$ of sediments above the terrace gravels (with the interval from 45 to $55 \mathrm{~cm}$ being a mixture of gravels and sediment), trench 2 showed $75 \mathrm{~cm}$ of sediments. The northern wall of trench 3 had the thickest sediment cover of $85 \mathrm{~cm}$. Trench 4 exhibited $25-30 \mathrm{~cm}$ of sediment covering the gravel.

Here, we focus on trench 3 because it was the largest excavated trench with the thickest sediment cover and the highest artifact density (Fig. 2). At Seňa I, trench 3, the excavations revealed an upper $30 \mathrm{~cm}$ representing a middle-brown plow horizon of a soil with a partly sub-polyhedral and partly friable structure and 3-10\% small to medium pebbles (up to $4 \mathrm{~cm}$ diameter) embedded (level 1A). The upper $20 \mathrm{~cm}$ contained more pebbles than the interval from 20 to $30 \mathrm{~cm}$ depth where their contribution decreases to $\sim 1 \%$. The interval from $\sim 30$ to $44 \mathrm{~cm}$ was a lighter brown plow horizon slightly enriched with clay (level 1B) with no pebbles. From $\sim 44$ to $64 \mathrm{~cm}$, a layer of loose loess (-like) sediment occurred containing a few small pebbles (level 2). The ochre-light brown color likely indicates a weak pedogenic overprint. From $\sim 64$ to $85 \mathrm{~cm}$, a slightly reddish-dark brown paleosol was observed containing about $5 \%$ pebbles (level $2 / 3$ ), followed by the terrace gravels (level 3). Grain size data show a multimodal distribution (Chu et al. 2018, their Fig. 9). Besides a peak in the grain size around 20-40 $\mu \mathrm{m}$, Seňa I also shows a coarser sandy component and an elevated clay content.

The results of the EMMA are 2-4 end members that describe most of the data variability, reducing data dimensions from the original 113 grain size classes (with variable data). Because the explained overall variability only slightly increases with a 4th end member, we use three end members here that in sum explain $58 \%, 81 \%$, and $84 \%$ of overall data variability, respectively. The three end members show (a) an end member with a dominant peak in the sand fraction centered at $\sim 550 \mu \mathrm{m}$ explaining $40 \%$ of end members, (b) an end member with dominance of a peak at $\sim 20-30 \mu \mathrm{m}$

Table $2{ }^{14} \mathrm{C}$ dating results of three samples from Seňa I. Trench 3

\begin{tabular}{lllllll}
\hline Lab code & ID code & Material & Weight & $\begin{array}{l}\text { Conventional } \\
\text { radiocarbon age }\end{array}$ & $\begin{array}{l}\text { Measured } \\
\text { Delta C13 }\end{array}$ & $\begin{array}{l}\text { Cal B.P. } \\
\text { (INTCAL13) }\end{array}$ \\
\hline Beta-444,099 & Seňa $27137 \mathrm{~cm}$ & Charcoal & $2 \mathrm{mg}$ & $130 \pm 30$ B.P. & -23.9 & $141 \pm 97$ \\
Beta-444,100 & Seňa $10840 \mathrm{~cm}$ & Charcoal & $324 \mathrm{mg}$ & $>43,500$ B.P. & -22.3 & N/A \\
Beta-444,101 & Seňa $28346 \mathrm{~cm}$ & Charcoal & $0.02 \mathrm{mg}$ & $310 \pm 30$ B.P. & -26.7 & $379 \pm 53$ \\
\hline
\end{tabular}


explaining $\sim 30 \%$ of end members, and (c) a component including side peaks of the previous components in the sand and silt fractions along with a strong clay/fine silt content in the $\sim 0.2-10 \mu \mathrm{m}$ grain size fraction representing $\sim 29 \%$ of end members.

\section{Excavation}

The excavated assemblage consists of over 278 artifacts (21 found in the wet sieving) along with two faunal remains. The latter were fragments smaller than $20 \mathrm{~mm}$ that were not further identifiable, and their poor surface preservation prohibited any assessment of anthropogenic modifications. No malacofauna remains were recovered. Three small ochre fragments (c. $10 \mathrm{~mm}$ in diameter) were also found in the excavation.

Lithic artifacts were mostly flakes and blade fragments or knapping debris made of heavily patinated limosilicites though some small pieces $(N<5)$ of radiolarite and obsidian were also recovered. Lithic artifacts indicative of an Aurignacian assemblage were three prismatic blade cores (Fig. 3), a nosed endscraper, various other forms of endscrapers, burins (Fig. 4), blade fragments (Fig. 5), and retouched flakes. Furthermore, the lithic artifacts varied in size (7-83 $\mathrm{mm}$ in maximum length) and weight (> 0.01-115.6 g) suggesting minimal redeposition reflected in typical differential movement of objects of different sizes (i.e., no size sorting). There was no clear pattern to horizontal artifact distribution, and there were no evidences for pits or other features.

\section{Age and Chronostratigraphy}

The age and chronostratigraphic position of level 2/3's Aurignacian artifacts is constrained by optically stimulated luminescence (OSL) dating. Obtained luminescence ages are stratigraphically consistent (Table 1; $33.5 \pm 2.4$; C-L4260, pIRIR 290 ), $24.0 \pm$ 1.6 (C-L4259, pIRIR 290 ) and 15.5 $\pm 1.1\left(\mathrm{C}-\mathrm{L} 4258, \mathrm{pIRIR}_{290}\right)$ and $\mathrm{pIRIR}_{290}$ and $\mathrm{IR}_{50}$ analyses of the same samples are in close agreement. This is a good internal control and supports the assumption that the pIRIR $_{290}$ signal has been completely bleached prior to deposition (Buylaert et al. 2012).

The three presented radiocarbon ages show no chronological pattern and are found higher than the luminescence samples, in or at the interface of plowed sediments (Table 2; Fig. 2). The small size (324 mg) and infinite age of Beta-444,100 suggest that it is likely geological (e.g., much older coal) as no visible striations were observed. The other samples were unidentifiable micro-charcoals $(<2 \mathrm{mg})$ that can be mobile in sediments and were not retrieved from in situ clearly visible hearths and were from later events that were incorporated into the plow zone during tillage. Therefore, these radiocarbon samples have no secure association with an archeologically recognizable event that could be related to an Aurignacian occupation.

\section{Discussion}

\section{Stratigraphy and Sedimentology}

At Seňa I, the grain size distribution (maximum distribution of $\sim 20-40 \mu \mathrm{m}$ ) of the sediment cover is highly similar to the pure loess sample from the well-studied 

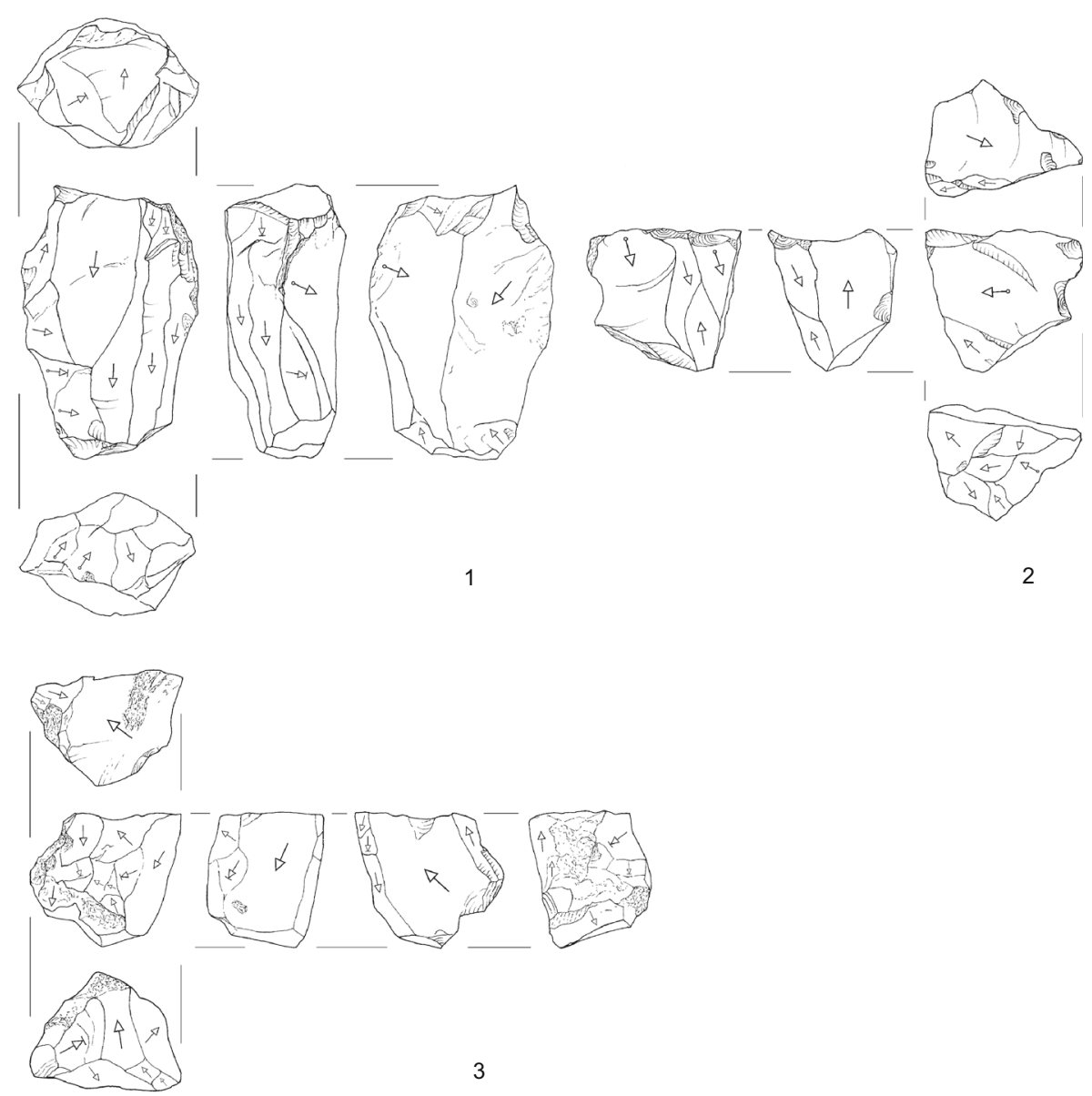

3
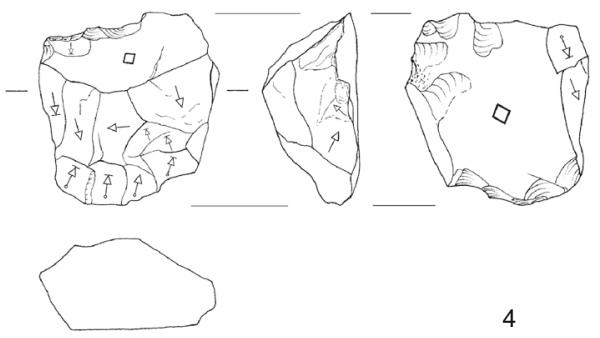

4 $5 \mathrm{~cm}$

Fig. 3 Seňa I 2015/16: Selection of blade and flake cores

reference site of Semlac, Romania (c. $200 \mathrm{~km}$ south; Chu et al. 2018; Zeeden et al. 2016a; Zeeden et al. 2016b). Eolian deposition from nearby river plains is common during cold climatic periods in the vicinity of rivers at the northern edge of the Carpathian Basin (see e.g., the literature on loess around Tokaj; e.g., Sümegi and Hertelendi 1998). Due to the site's position on a water permeable terrace, eolian 

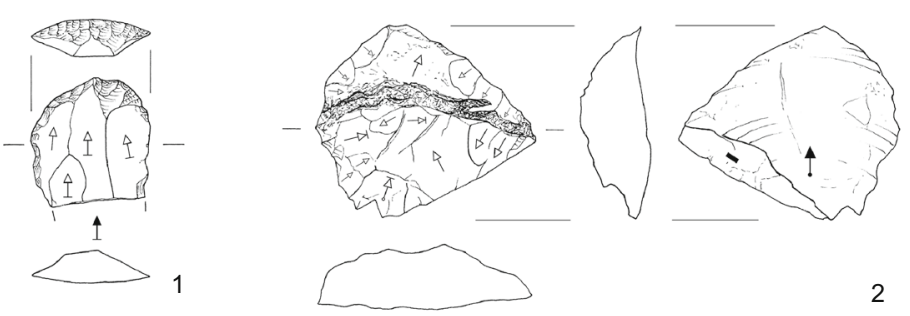

2
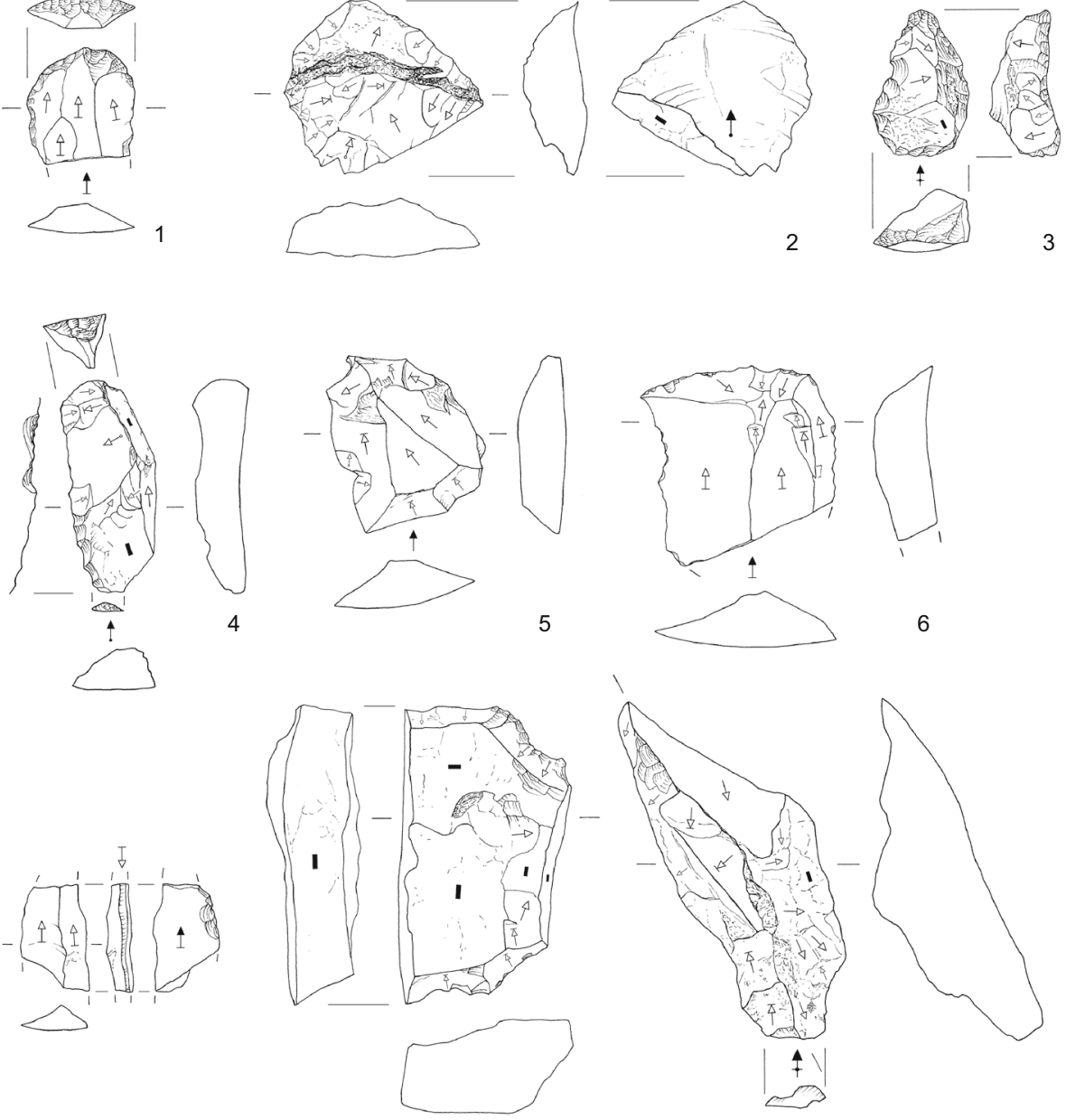

7

8

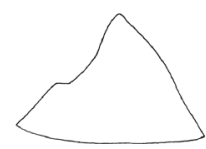

9

0 $5 \mathrm{~cm}$

Fig. 4 Sen̆a I 2015/16: Selection of the following tools: 1, 2, 4, 6-endscrapers; 3-nosed endscraper; 5-notch; 7burin; 8-denticulate; 9-crested blade

sediment erosion probably did not occur during initial sedimentation on top of the gravels where the majority of the artifacts were found, but may have developed later with increased eolian deposition and heavy precipitation.

There is an additional eolian coarser sandy component interpreted to come from the close-by Hornád River flood plain. The topographic position on a river terrace makes a major contribution of slope material unlikely because of both low slope angle and high water permeability of the underlying terrace and the eolian sediment. A smaller clay component was also present that is typical for pedogenetically overprinted loess in the region (e.g., Bodrogkeresztúr; $45 \mathrm{~km}$ south; Bösken et al. 2017). In the lower levels 2 and $2 / 3$, pebbles $(5 \%)$ occur in the eolian sediment mixed in from the underlying 

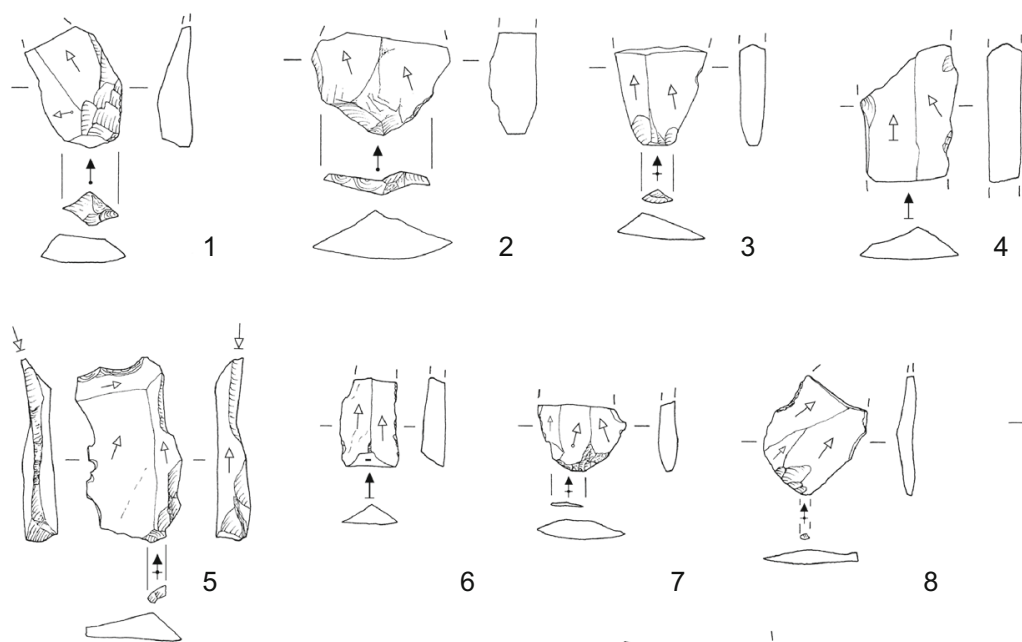

6
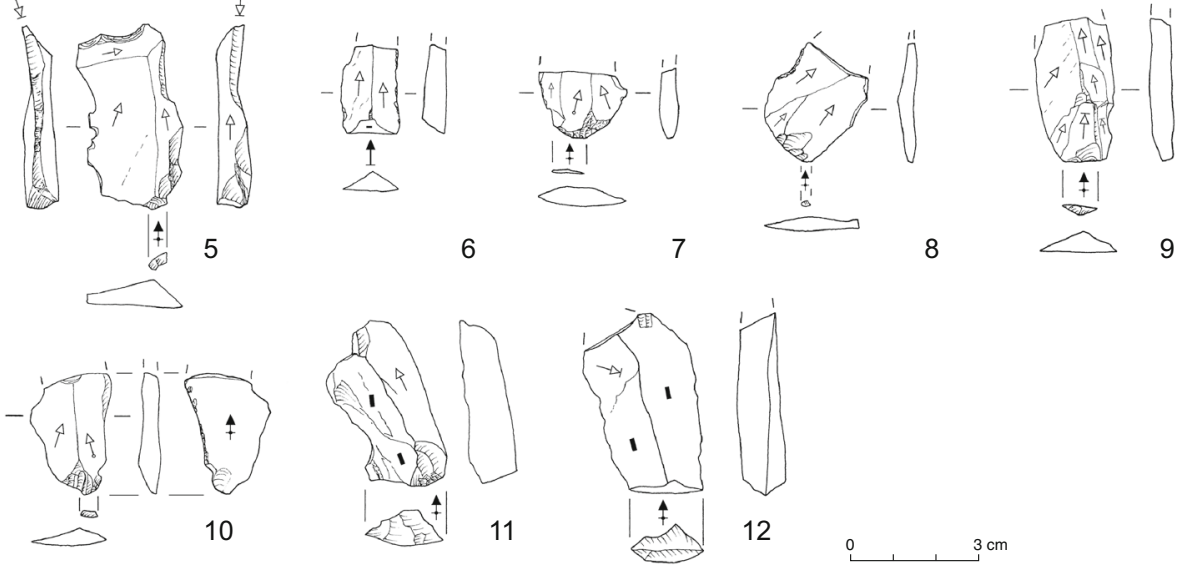

9

Fig. 5 Seňa I 2015/16: Selection of blade/bladelet (fragment) blanks

terrace gravels based on similar size, shape, and lithology. Larger stones are present in level $1 \mathrm{~A}$ and are abundant on the surface that were brought into the soil by regular plowing from the terrace edge where sediment cover is thin and the topsoil is mixed with stones from the terrace through plowing.

The three end members of the grain size distribution are depicted in Fig. 6 and describe fine (clay and fine silt; EM3), silt (EM1), and sand fractions (EM2). The
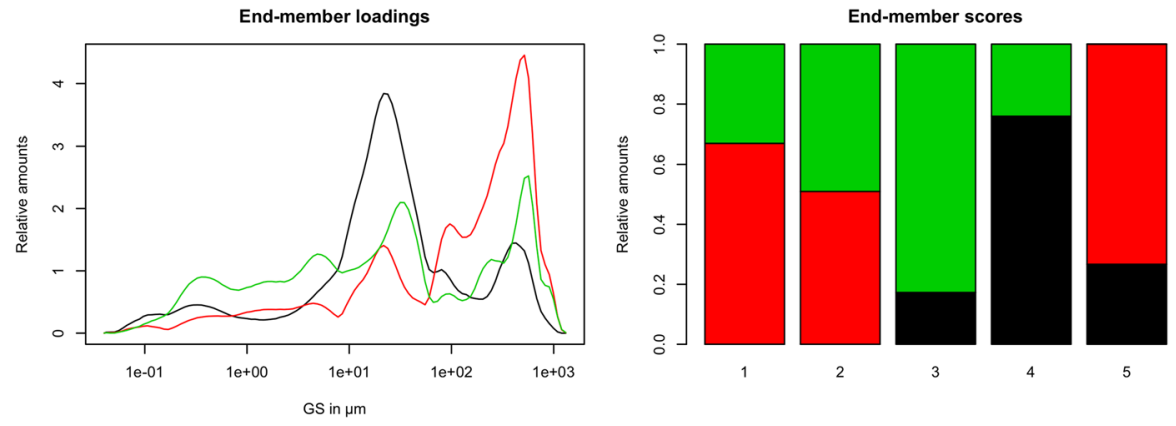

End-member ID (mode position | explained variance)

$-\operatorname{EM} 1(22 \mid 30 \%)-\operatorname{EM} 2(520 \mid 40 \%)-\operatorname{EM} 3(570 \mid 29 \%)$

Fig. 6 End member modeling (Dietze et al. 2013) of grain size data (Chu et al. 2018). Analysis shows three prominent end members and their grain size loadings (left). On the right, the contributions of the three end members are shown for samples taken in $12.5,27.5,32,39.5$, and $57 \mathrm{~cm}$ depth. At the bottom, the color scheme is plotted, and the modes of end members in $\mu \mathrm{m}$ are given together with the contributions of end members to the overall explained variance (here $81 \%$ of variability) 
topmost plow zone samples are explained through a combination of the end members representing clay and sand indicating eolian sediment with some sand that may originate from stronger winds during the Holocene (Obreht et al. 2015). A dark gray chernozem-like soil is found at the top, but is disturbed through plowing in the upper $\sim 45 \mathrm{~cm}$. While the boundaries between sediment packages were spatially undulating, bioturbation was minor, and no crotovinas and major root channels were observed. The lowermost sample (level 2) can be approximated by the end members representing sand and silt, where sand from the underlying terrace was mixed with the eolian sediment.

The sedimentological findings and the here presented interpretation suggest that lithic artifacts were deposited close to the gravel surface and later covered by more eolian sediment deposits. Whether artifacts were deposited directly on the gravel surface or on an existing weak paleosol cannot be reconstructed from the limited excavation and also due to apparently slow sedimentation. Post-depositional processes later affected the vertical distribution of material through both mixing with the terrace gravels and sand (lowermost of the eolian sediment sample contains sand probably from terrace material), and much later plowing of the profile top which distributed stones including artifacts from the terrace edge over a wider area. This would be consistent with the open-air nature of the site and can explain the low density of lithics and the heavy patina. The upward fining of artifacts and pebbles in the lower profile corresponds with this scenario.

\section{Excavation}

The results of our excavation were similar to those of Bánesz in terms of position, artifact density, raw materials, and typo-technology, allowing a straightforward correlation with the 1955 excavation. Disregarding the subdivisions of our stratigraphy and varying depths, the geological levels agree with those previously observed. While our main find concentration was in contact with the terrace gravels, we also found that artifacts continued $15 \mathrm{~cm}$ upwards and that errant typologically analogous artifacts were found higher up in the stratigraphy and on the surface. The latter is due to truncation and redeposition by current and historical plowing of zones (c. $45 \mathrm{~cm}$ ) where the sedimentary sequence was notably shallower (e.g., trench 4). While excavated finds may have migrated as a result of bioturbation within the paleosol and also due to mixing with underlying gravels, the precision and coherent chronological succession of our luminescence ages, combined with sedimentostratigraphy, demonstrate an integrity of the main find level sediments and indicate a discrete archeological deposition with limited reworking. Furthermore, the spread in ages over a shallow sequence suggests a sustained period of occupation under relatively low sedimentary deposition. The low sedimentation rates compared with sites within the Carpathian Basin can be explained by the limited sediment input from the Hornád River floodplain.

While the excavated trenches were too small to reliably identify horizontal artifact concentrations, they did reveal variable artifact density with some areas yielding higher artifact density than others. This suggests differences in spatial variability potentially representing activity areas, but the stochastic distribution of artifact types does not allow us to make further inference. 
Artifacts were primarily manufactured on local limnosilicite that was later heavily patinated possibly as a result of long aerial exposure under fluctuating climate and environmental conditions (Glauberman and Thorson 2012; Thiry et al. 2014) that may be inferred from our short sedimentary sequence over a long timeframe. There was a single radiolarite core and a single knapped obsidian nodule from the site; it is remarkable that obsidian was so infrequently used as the raw material source is semilocal $(40 \mathrm{~km})$ and as, curiously, obsidian from the same source is frequently found at Aurignacian sites in Romania some 170 km away (Dobrescu et al. 2018).

The artifact types throughout the sequence are consistent with Bánesz's collection, an assemblage with flake and blade production and many endscrapers including a nosed endscraper. Combined with the artifacts from Bánesz's excavation, we can (re-)ascribe this assemblage to the Aurignacian from central Europe based on blade production, burins, and endscrapers (including typical carinated/-nosed endscrapers; Davies 2001) and the absence of both earlier and later fossiles directeurs such as leaf points for the Szeletian, Levallois-like core technology for the Bohunician, and backed bladelets for the Gravettian (Moreau et al. 2015; Škrdla 2017b; Svoboda 2006). Due to the relative absence of further diagnostic tools (e.g., specific burin types, Góra Puławska II-type microliths; Demidenko et al. 2017), it is currently not possible to ascribe it further to subindustries.

\section{Age and Chronostratigraphy}

The chronostratigraphic position of Seňa I indicates by proxy that modern humans were present in the northern Carpathian Basin by $33.5 \pm 2.4 \mathrm{ka}$ ago based on the lithics overlying the gravels and the associated luminescence ages of the embedding sediments (Table 1, C-L4260). As the luminescence ages represent the date of the sediment deposition, however, the human occupation may be older. Artifacts are also found higher in the same level at the date of $24.0 \pm 1.6 \mathrm{ka}$ (C-L4259) and may indicate a sustained occupation of the site, though it is possible that they may have in part migrated upwards due to frost heaving or other processes. No artifacts were found in level 2 which was dated to $15.5 \pm 1.1 \mathrm{ka}$ ago (C-L4258). As occasional artifacts were found higher up in the contact zone between $1 \mathrm{~b}$ and 2 as well as on the surface, we attribute these to reworking by plowing of areas where the sequences were notably shallower (e.g., trench 4).

This oldest age is in agreement with the previous radiocarbon ages (Table 3) from nearby Košice-Barca I (29.68 \pm 0.25 ky (uncal) B.P.; GrA-16,157) and Kechnec $(27.55$ \pm 0.14 ky (uncal) B.P.; OxA-15,678 and $27.37 \pm 0.21$ ky (uncal) B.P.; GrA-24,329) and is supported by the modern human occipital bone from Görömböly-Tapolca $(30.3 \pm 0.2$ ky (uncal) B.P.; OxA-15,080; Davies and Hedges 2008; Thoma and Vértes 1975) and the modern human molar from Istállós-kő (Bailey et al. 2009; Malán 1955; Tillier et al. 2006; Vértes 1955) possibly dated to 31-28 ky (uncal) B.P. in northern Hungary (Adams and Ringer 2004).

The Hornád Valley ages are also concurrent with the Aurignacian sites of Dzeravá skala cave in Western Slovakia where two typical Mladeč points (Kaminská et al. 2005) were dated to $31.6 \pm 0.9$ (OxA-15,534) and 31.0 $\pm 1.1 \mathrm{ky}$ (uncal) B.P. (OxA-15,535; Davies and Hedges 2005; Kaminská et al. 2005; Figs. 25/4 and 25/5). In the neighboring Moravian Basin, Czech Republic, the directly dated modern human teeth at Mladeč at c. 31 ky (uncal) B.P. (Wild et al. 2005) are complimented by Aurignacian 


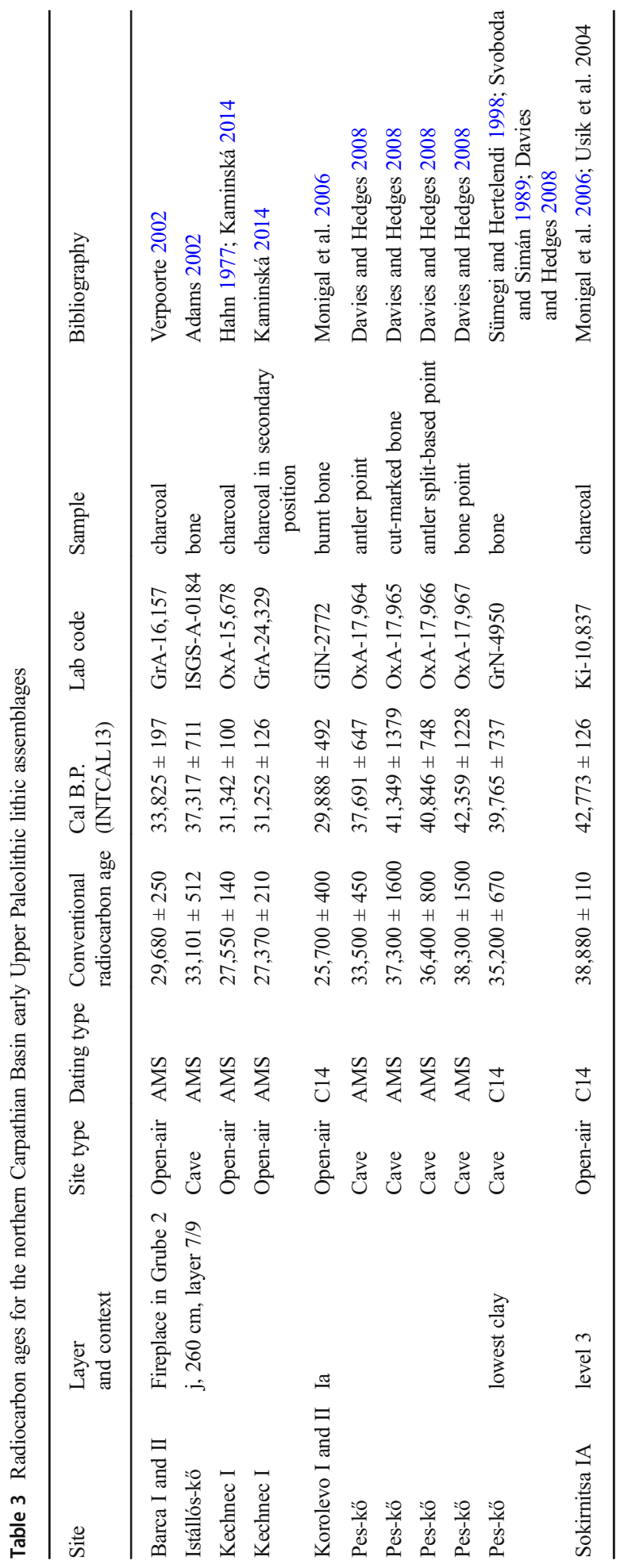


assemblages (e.g., Stranska Skála, Pod Hradem) similarly dated to between 33 and 29 ky (uncal) B.P. (Nejman et al. 2017; Škrdla 2017a). Slovenian cave sites yielding Aurignacian bone and lithic industries that were thought to be younger were recently redated to between 32 and $27 \mathrm{ky}$ (uncal) B.P. (Moreau et al. 2015).

There are older ages for the Aurignacian in the northern Carpathian Basin in the Bükk Mountains though they are problematic. At Pes-kő cave, the earliest directly dated artifact is a bone point $(38.3 \pm 0.15 \mathrm{ky}$ (uncal) B.P.; OxA-17,967; Davies and Hedges 2008), though it and the associated lithic artifacts cannot clearly be assigned to the Aurignacian technocomplex (Lengyel et al. 2006). Davies and Hedges (2008) also reported radiocarbon ages from two other split-based points ( $36.4 \pm 0.8 \mathrm{ky}$ (uncal) B.P.; OxA-17,966 and 33.5 \pm 0.45 ky (uncal) B.P.; OxA-17,964); however, neither Mottl (1942) nor Kadić (1944), the original excavators of the cave, published any split-based osseous artifacts, and Vértes (1965) later questioned this classification for the tools. In the Istállós-kö cave's lower layer assemblage, the split-based points are uncontested though they mostly failed to produce enough datable material, and the only two reliable ages (34.8 ky (uncal) B.P.; OxA-X-2244-32, 33.6 ky (uncal) B.P.; OxA-X-2170-18) were obtained from simple undiagnostic antler points (Davies and Hedges 2008).

In the Transcarpathian Ukraine, blade industries at Korolevo (I level Ia; II/II) and Sokirnitsa IA level 3 have been dated to around 39 ka B.P. through pollen, radiocarbon, $\mathrm{TL}$, and paleomagnetic dating, though the various proxies are not always in agreement and the conflicting evidence suggests that they may be younger (Monigal et al. 2006; Usik et al. 2003). Additionally, the absence of diagnostic tools at both sites makes it difficult to ascribe them to the Aurignacian and they may be culturally related to the Szeletian or Bohunician. However, if the assemblages are indeed younger, Transcarpathia may be connected to the Hornád Valley sites by Ukrainian Volhynia flint at several other sites in the Hornád and by vitrophyric dacite (i.e., andesite) from Korolevo at the Aurignacian site of Kladzany in the Ondava river basin (Kaminská et al. 2000).

West of the northern Carpathian Basin in Lower Austria, the earliest Aurignacian in Europe at Willendorf II AH3 was modeled to 39.5 ky (uncal) B.P. based on climatostratigraphy and radiocarbon ages (Haesaerts et al. 1996; Nigst et al. 2014), but both the chronology and cultural attribution of the assemblage have been contested (Teyssandier and Zilhão 2018; Zilhão and d'Errico 1999). Furthermore, the ages are old for other dated Aurignacian assemblages in the area (e.g., Krems-Hundssteig, Senftenberg, Grossweikersdorf) that are assigned to between 34 and 31 ky (uncal) B.P. (Nigst and Haesaerts 2012; Wild et al. 2008).

In sum, while there are a range of varying ages for the early Upper Paleolithic in the northern Carpathian Basin and its immediate surroundings, direct numerical chronologies for hominin remains and secure Aurignacian assemblages all center around 34 29 ky (uncal) B.P.

\section{Implications}

Our results, along with the high concentration of other large, close-by sites (e.g., Barca and Kechnec localities and other findspots), indicate that by 34 ka B.P., the Aurignacian technocomplex was well established along the Hornád Valley as part of an expanding population in eastern central Europe with the site reflecting a potential seasonal population (Schmidt and Zimmermann 2019; Svoboda 2006) in an area where abundant resources 
were located within a modest walking radius ( $<5 \mathrm{~h}$; Hauck et al. 2018). If the purported habitation structures, storage pits, and other "site furniture" from Barca (I, II, and III), Seňa I and Tibava are indeed supported (which is still controversial); they would also strongly intimate a sustained occupation at least on a semi-regular basis (Binford 1979).

For the moment, our ages contribute to a minimum age for the Aurignacian assemblage at Seňa I, and consequently cannot contribute to the question of synchrony with preceding regional industries such as the Szeletian or Bohunician. However, the notable absence of these earlier technocomplexes from the Hornád Basin that are well known from neighboring regions suggests that Aurignacian settlements in the region do not clearly map onto preceding (or subsequent) technocomplexes and may be the result of preferential landscape use, possibly mitigated by changes in climate and environment (Staubwasser et al. 2018).

\section{Conclusions and Future Perspectives}

The presence and timing of the early Upper Paleolithic in eastern central Europe remains a vital part of understanding the nature of transitional industries and the first modern human occupation of Europe during the mid-Pleniglacial. New excavations combined with sedimentological analysis at the site of Seňa I reconfirm the presence of a rare stratified Aurignacian site in the region. Robust radiometric ages from the main find level confirm a chronology for the assemblage before $33.5 \pm 2.4 \mathrm{ka}$.

These results corroborate earlier radiometric ages on hominin remains and archeological assemblages from the surrounding regions. While our current work adds to the corpus of early Upper Paleolithic research in central Europe, future efforts should continue to focus on the identification and dating of stratified archeological sites where lithic/faunal studies can contribute to our understanding of the relationship between the various early Upper Paleolithic assemblages where clear delineations are either blurred or not fully understood. However, such sites are exceedingly rare in the Carpathian Basin, and in their absence, future research at sites such as Seňa I should exploit geoarchaeological advances in physical and chemical techniques such as micromorphology, magnetic susceptibility, and geochemistry that may help to further elaborate site formation processes and their implications for early hominin behavioral patterns.

Acknowledgments We would like to thank the excavation teams from the University of Cologne and Eötvös Loránd University and to Marian Jambrich for logistical support. Luminescence samples were processed at the Cologne Luminescence Laboratory. Thank you to Andreas Bolten for creating Fig. 1, Anja Rueschmann for the artifact drawings, Thomas Albert for his help creating Fig. 2, and to Jürgen Richter and Isabell Schmidt for helpful discussions.

Funding Information This study was funded by the Deutsche Forschungsgemeinschaft (DFG, German Research Foundation)-Project Number 57444011 - SFB 806; and as part of Project no. APVV-16-0383 (Slovakia). G. L. was supported by the ÚNKP-19-4P New National Excellence Program of the Ministry for Innovation and Technology (TNRT/1419/51/2019), and the Bolyai János Research Fellowship (BO/00629/19/ 2) of the Hungarian Academy of Sciences (MTA).

\section{Compliance with Ethical Standards}

Conflict of Interest The authors declare that they have no conflict of interest. 
Open Access This article is distributed under the terms of the Creative Commons Attribution 4.0 International License (http://creativecommons.org/licenses/by/4.0/), which permits unrestricted use, distribution, and reproduction in any medium, provided you give appropriate credit to the original author(s) and the source, provide a link to the Creative Commons license, and indicate if changes were made.

\section{References}

Adams, B. (2002) 'New radiocarbon dates from Szeleta and Istállóskő caves, Hungary', Praehistoria, 3, pp. 53-55.

Adams, B., \& Ringer, A. (2004). New c14 dates for the Hungarian early upper Palaeolithic. Current Anthropology, 45(4), 541-551. https://doi.org/10.1086/ca.2004.45.issue-4.

Aitken, M. J. (1985). Thermoluminescence dating. London: Academic Press.

Anghelinu, M., \& Niță, L. (2014). What's in a name: The Aurignacian in Romania. Quaternary International, $351,172-192$.

Auclair, M., Lamothe, M., \& Huot, S. (2003). Measurement of anomalous fading for feldspar IRSL using SAR. Radiation Measurements, 37(4), 487-492. https://doi.org/10.1016/S1350-4487(03)00018-0.

Bailey, S. E., Weaver, T. D., \& Hublin, J.-J. (2009). Who made the Aurignacian and other early upper Paleolithic industries? Journal of Human Evolution, 57, 11-26.

Bánesz, L. (1958). Mladopaleolitické objekty v Seni I. Slovenska Archeologia, 6(1), 5-20.

Bánesz, L. (1968). Ortsbestimmung der Paläolithischen fundstellen bei Barca. In Barca bei Košice: Paläolithische Fundstelle (pp. 7-20). Bratislava: Vydavatelstvo Slovenskej Akademie Vied.

Bánesz, L. (1989). Problems of the upper Palaeolithic in the north-western part of the Carpathian Basin. Anthropologie, 27(2/3), 245-249.

Bell, W. T. (1980). Alpha dose attenuation in quartz grains for thermoluminescence dating. Ancient TL, 12, 4 8.

Binford, L. R. (1979). Organization and formation processes: Looking at curated technologies. Journal of Anthropological Research., 35, 255-273.

Bösken, J., Obreht, I., Zeeden, C., Klasen, N., Hambach, U., Sümegi, P., \& Lehmkuhl, F. (2017). Highresolution paleoclimatic proxy data from the MIS3/2 transition recorded in northeastern Hungarian loess. Quaternary International. https://doi.org/10.1016/j.quaint.2017.12.008.

Buylaert, J.-P., Jain, M., Murray, A. S., Thomsen, K. J., Thiel, C., \& Sohbati, R. (2012). A robust feldspar luminescence dating method for middle and Late Pleistocene sediments. Boreas, 41(3), 435-451. https://doi.org/10.1111/j.1502-3885.2012.00248.x.

Chu, W. (2018). The Danube corridor hypothesis and the Carpathian Basin: Geological, environmental and archaeological approaches to characterizing Aurignacian dynamics. Journal of World Prehistory, 31(2), 117-178. https://doi.org/10.1007/s10963-018-9115-1.

Chu, W., Lengyel, G., Zeeden, C., Péntek, A., Kaminská, L., \& Mester, Z. (2018). Early upper Paleolithic surface collections from loess-like sediments in the northern Carpathian Basin. Quaternary International, 485, 167-182. https://doi.org/10.1016/j.quaint.2017.05.017.

Davies, W. (2001). A very model of a modern human industry: New perspectives on the origins and spread of the Aurignacian in Europe. Proceedings of the Prehistoric Society, 67, 195-217. https://doi.org/10.1017 /S0079497X00001663.

Davies, W., \& Hedges, R. (2005). Dating the middle-to-upper Palaeolithic transition: A new chronometric framework. In L'. Kaminská, J. K. Kozłowski, \& J. Svoboda (Eds.), Pleistocene environments and archaeology of the Dzeravá Skala cave, lesser Carpathians, Slovakia (pp. 59-66). Krakow: Polska Akademia Umiejętności.

Davies, W., \& Hedges, R. (2008). Dating a type site: Fitting Szeleta cave into its regional chronometric context. Praehistoria, 9, 35-45.

Demars, P.-Y. (1992). L’Aurignacien ancien en Périgord. Le problème du Protoaurignacien. Paléo, 4(1), 101122. https://doi.org/10.3406/pal.1992.1197.

Demidenko, Y. E., Škrdla, P., \& Nejman, L. (2017). Aurignacian in Moravia: New geochronological, lithic and settlement data. Pamatky Archeologicke, 108, 5-38.

Dobosi, V. (1995). Eger-Köporostetö. Révision d'une industrie à outils foliacés. Paléo. Supplément, 1(1), 4555. https://doi.org/10.3406/pal.1995.1379.

Dobosi, V. (2013). Acsa-Rovnya: új eredmények (Acsa-Rovnya: new results). Litikum, 1, 50-59.

Dobrescu, R. (2008). Aurignacianul din Transilvania. Bucharest: Renaissance. 
Dobrescu, R., Tuffreau, A., \& Bonsall, C. (2018). L'utilisation de l'obsidienne au Paléolithique supérieur dans le nord-ouest de la Roumanie. L'Anthropologie, 122(2), 111-128. https://doi.org/10.1016/j. anthro.2018.02.002.

Durcan, J. A., King, G. E., \& Duller, G. A. T. (2015). DRAC: Dose rate and age calculator for trapped charge dating. Quaternary Geochronology, 28, 54-61. https://doi.org/10.1016/j.quageo.2015.03.012.

Frechen, M., Schweitzer, U., \& Zander, A. (1996). Improvements in sample preparation for the fine grain technique. Ancient TL, 14(2), 15-17.

Glauberman, P., \& Thorson, R. (2012). Flint patina as an aspect of "flaked stone taphonomy": A case study from the loess terrain of the Netherlands and Belgium. Journal of Taphonomy, 10(1), 21-43.

Guérin, G., Mercier, N., \& Adamiec, G. (2011). Dose-rate conversion factors: Update. Ancient TL, 29(1), 5-8.

Guérin, G., Mercier, N., Nathan, R., Adamiec, G., \& Lefrais, Y. (2012). On the use of the infinite matrix assumption and associated concepts: A critical review. Radiation Measurements, 47, 778-785.

Haesaerts, P., Damblon, F., Bachner, M., \& Trnka, G. (1996). Revised stratigraphy and chronology of the Willendorf II sequence, Lower Austria. Archaeologia Austriaca, 80, 25-42.

Hahn, J. (1977). Aurignacien, das ältere Jungpaläolithikum in Mittel-und Osteuropa. Cologne: Böhlau.

Hauck, T. C., Lehmkuhl, F., Zeeden, C., Bösken, J., Thiemann, A., \& Richter, J. (2018). The Aurignacian way of life: Contextualizing early modern human adaptation in the Carpathian Basin. Quaternary International, 485, 150-166.

Hauck, T., Rethemeyer, J., Rentzel, P., Schulte, P., Fulop, R., Heinze, A., et al. (2016). Neandertals or early modern humans? A revised 14C chronology and geoarchaeological study of the Szeletian sequence in Szeleta cave (Hungary). Archäologisches Korrespondenzblatt, 46(3), 271-290.

Huntley, D. J., \& Baril, M. R. (1997). The K content of the K-feldspars being measured in optical dating or in thermoluminescence dating. Ancient TL, 15(1), 11-13.

Huntley, D. J., \& Lamothe, M. (2001). Ubiquity of anomalous fading in K-feldspars and the measurement and correction for it in optical dating. Canadian Journal of Earth Sciences, 38(7), 1093-1106. https://doi. org/10.1139/e01-013.

Inizan, M.-L., \& Féblot-Augustins, J. (Eds.). (1999). Technology and terminology of knapped stone: Followed by a multilingual vocabulary - Arabic, English, French, German, Greek, Italian, Portuguese, Spanish. Nanterre: CREP.

Kadić, O. (1944). Die Höhle des nordwestlichen Bükkgebirges. Barlangkutatás (Höhlenforschung), 17(1), 85-111.

Kaminská, L. (2013). Sources of raw materials and their use in the Palaeolithic of Slovakia. In Z. Mester (Ed.), The lithic raw material sources and interregional human contacts in the northern Carpathian regions (pp. 99-109). Krakow: Polska Akademia Umiejętności.

Kaminská, L. (2014). Staré Slovensko 2 (Vol. 2). Nitra: Archeologický Ústav Sav Nitra.

Kaminská, L., Kozłowski, J. K., \& Svoboda, J. (2005). Sequence of the Palaeolithic occupations. In L. Kaminská, J. K. Kozłowski, \& J. Svoboda (Eds.), Pleistocene environments and archaeology of the Dzeravá skala cave, lesser Carpathians, Slovakia (pp. 7-58). Krakow: Polska Akademia Umiejętności.

Kaminská, L., Kozłowski, J., Kazior, B., Pawlikowski, M., \& Sobczyk, K. (2000). Long term stability of raw materials procurement systems in the middle and upper Palaeolithic of eastern Slovakia: A case study of the Topla/Ondava river valleys. Praehistoria, 1, 63-81.

Kozłowski, J. K., Mester, Z., Budek, A., Kalicki, T., Moskal-del Hoyo, M., Zandler, K., \& Béres, S. (2012). La mise en valeur d'un ancien site éponyme: Eger-Kőporos dans le Paléolithique moyen et supérieur de la Hongrie du nord. L'Anthropologie, 116(3), 405-465. https://doi.org/10.1016/j.anthro.2012.05.004.

Kozłowski, J. K., Mester, Z., Zandler, K., Budek, A., Kalicki, T., Moskal, M., \& Ringer, Á. (2009). Le Paléolithique moyen et supérieur de la Hongrie du nord: nouvelles investigations dans la région d'Eger. L'Anthropologie, 113(2), 399-453. https://doi.org/10.1016/j.anthro.2009.04.005.

Lengyel, G., Béres, S., \& Fodor, L. (2006). New lithic evidence of the Aurignacian in Hungary. Eurasian Prehistory, 4(1-2), 79-85.

Lengyel, G., \& Mester, Z. (2008). A new look at the radiocarbon chronology of the Szeletian in Hungary. Eurasian Prehistory, 57, 73-83.

Malán, M. (1955). Zahnkeim aus der zweiten Aurignacien Schicht der Höle von Istállóskő. Acta Archaeologica Academiae Scientiarum Hungaricae, 5(1/2), 145-148.

Markó, A. (2015). Considerations on the lithic assemblages from the Szeleta cave. Communicationes Archaeologicae Hungariae, 2015-2016, 5-44.

Markó, A., Péntek, A., \& Béres, S. (2002). Chipped stone assemblages from the environs of Galgagyörk (northern Hungary). Praehistoria, 3, 245-258.

Monigal, K. et al. (2006) 'The beginning of the Upper Paleolithic in Transcarpathia, Ukraine', Anthropologie, 44(1), pp. 61-75. 
Moreau, L., Odar, B., Higham, T., Horvat, A., Pirkmajer, D., \& Turk, P. (2015). Reassessing the Aurignacian of Slovenia: Techno-economic behaviour and direct dating of osseous projectile points. Journal of Human Evolution, 78, 158-180.

Mottl, M. (1942). Das Aurignacien in Ungarn. Quartar, 4, 82-108.

Nejman, L., Wood, R., Wright, D., Lisá, L., Nerudová, Z., Neruda, P., et al. (2017). Hominid visitation of the Moravian karst during the middle-upper Paleolithic transition: New results from pod Hradem cave (Czech Republic). Journal of Human Evolution, 108, 131-146. https://doi.org/10.1016/j. jhevol.2017.03.015.

Nigst, P. R., \& Haesaerts, P. (2012). The Aurignacian in eastern Austria: Preliminary results of an analysis of the lithic technology of archaeological horizon 3 at Willendorf II, and its implications for the chronology of the early upper Palaeolithic in Central Europe. Anthropologie, 116(4), 575-608.

Nigst, P. R., Haesaerts, P., Damblon, F., Frank-Fellner, C., Mallol, C., Viola, B., et al. (2014). Early modern human settlement of Europe north of the Alps occurred 43,500 years ago in a cold steppe-type environment. Proceedings of the National Academy of Sciences, 201412201. https://doi.org/10.1073 /pnas. 1412201111.

Obreht, I., Zeeden, C., Schulte, P., Hambach, U., Eckmeier, E., Timar-Gabor, A., \& Lehmkuhl, F. (2015). Aeolian dynamics at the Orlovat loess-paleosol sequence, northern Serbia, based on detailed textural and geochemical evidence. Aeolian Research, 18, 69-81. https://doi.org/10.1016/j.aeolia.2015.06.004.

Patou-Mathis, M., Vercoutère, C., Lengyel, G., Szolyák, P., \& Mester, Z. (2016). New interpretation of the upper Palaeolithic human occupations at the Istállóskő cave (Bükk Mountains, Hungary). Eurasian Prehistory, 13, 77-90.

Prescott, J. R., \& Hutton, J. T. (1994). Cosmic ray contributions to dose rates for luminescence and ESR dating: Large depths and long-term time variations. Radiation Measurements, 23(2), 497-500. https://doi. org/10.1016/1350-4487(94)90086-8.

Preusser, F. (2003). IRSL dating of K-rich feldspars using the SAR protocol: Comparison with independent age control. Ancient TL, 21, 17-23. https://doi.org/10.7892/boris.86653.

Prošek, F. (1953). Szeletien na Slovensku. Slovenská Archeológia, 1, 133-194.

R Core Team (2018). R: A language and environment for statistical computing. R Foundation for Statistical Computing, Vienna, Austria. URL https://www.R-project.org/.

Schmidt, C., Bösken, J., \& Kolb, T. (2018). Is there a common alpha-efficiency in polymineral samples measured by various infrared stimulated luminescence protocols? Geochronometria, 45, 160-172.

Schmidt, I., \& Zimmermann, A. (2019). Population dynamics and socio-spatial organization of the Aurignacian: Scalable quantitative demographic data for western and Central Europe. PLoS One, 14, e0211562.

Škrdla, P. (2017a). Moravia at the onset of the upper Paleolithic. Brno: Czech Academy of Science, Institute of Archaeology.

Škrdla, P. (2017b). Middle to upper Paleolithic transition in Moravia: New sites, new dates, new ideas. Quaternary International, 450, 116-125. https://doi.org/10.1016/j.quaint.2016.07.029.

Staubwasser, M., Drăgușin, V., Onac, B. P., Assonov, S., Ersek, V., Hoffmann, D. L., \& Veres, D. (2018). Impact of climate change on the transition of Neanderthals to modern humans in Europe. Proceedings of the National Academy of Sciences, 115, 9116.

Sümegi, P., \& Hertelendi, E. (1998). Reconstruction of microenvironmental changes in the Kopasz Hill loess area at Tokaj (Hungary) between 15 and 70 ka BP. Radiocarbon, 40(2), 855-863.

Svoboda, J. (2006). The Aurignacian and after: Chronology, geography and cultural taxonomy in the middle Danube region. In O. Bar-Yosef \& J. Zilhão (Eds.), Towards a definition of the Aurignacian (pp. 259274) Instituto Português de Arqueologia.

Svoboda, J. \& Simán, K. (1989) 'The Middle-Upper Paleolithic transition in Southeastern Central Europe (Czechoslovakia and Hungary)'. Journal of World Prehistory, 3(3), 283-322. https://doi.org/10.1007 /BF00975325.

Teyssandier, N., \& Zilhão, J. (2018). On the entity and antiquity of the Aurignacian at Willendorf (Austria): Implications for modern human emergence in Europe. Journal of Paleolithic Archaeology. https://doi. org/10.1007/s41982-017-0004-4.

Thiel, C., Buylaert, J.-P., Murray, A., Terhorst, B., Hofer, I., Tsukamoto, S., \& Frechen, M. (2011). Luminescence dating of the Stratzing loess profile (Austria) - Testing the potential of an elevated temperature post-IR IRSL protocol. Quaternary International, 234(1), 23-31. https://doi.org/10.1016/j. quaint.2010.05.018.

Thiry, M., Fernandes, P., Milnes, A., \& Raynal, J.-P. (2014). Driving forces for the weathering and alteration of silica in the regolith: Implications for studies of prehistoric flint tools. Earth-Science Reviews, 136, 141154. https://doi.org/10.1016/j.earscirev.2014.05.008. 
Thoma, A., \& Vértes, L. (1975). Hungary. In K. P. Oakley, B. G. Campbell, \& T. I. Molleson (Eds.), Catalogue of fossil hominids (Vol. 2). British museum (natural history).

Tillier, A.-M., Mester, Z., Henry-Gambier, D., Pap, I., Ringer, A., \& Gyenis, G. (2006). The middle-upper Palaeolithic transition in Hungary: An anthropological perspective. In V. Cabrera Valdés, F. B. De Quiros Guidotti, \& J. M. M. Fernandez (Eds.), En el centenario de la cueva de El Castillo: el ocaso de los Neandertales (pp. 90-106). Distancia: Universidad Nacional de Educacion a Distancia en Cantabria.

Tuffreau, A., Dobrescu, R., Balescu, S., \& Valeanu, M. C. (2013). Boinești (département de Satu-Mare) : Moustérien, Aurignacien et processus taphonomiques. Materiale şi Cercetări Arheologice, 9, 7-40.

Verpoorte, A. (2002). Radiocarbon dating the upper Palaeolithic of Slovakia: Results, problems and prospects. Archäologisches Korrespondenzblatt, 32(3), 311-325.

Vértes, L. (1955). Neuere Ausgrabungen und Paläolithische Funde in der Höhle von Istállóskő. Acta Archaeologica Academiae Scientiarum Hungaricae, 5, 111-131.

Vértes, L. (1965). Az öskökor és az átmeneti kökor emlékei Magyarországon (Records of the Palaeolithic and Mesolithic in Hungary). Budapest: Akadémiai Kiadó.

Wallinga, J., Murray, A., \& Wintle, A. (2000). The single-aliquot regenerative-dose (SAR) protocol applied to coarsegrain feldspar. Radiation Measurements, 32(5), 529-533. https://doi.org/10.1016/S1350-4487(00)00091-3.

Wild, E. M., Neugebauer-Maresch, C., Einwögerer, T., Stadler, P., Steier, P., \& Brock, F. (2008). 14C dating of the upper Paleolithic site at Krems-Hundssteig in Lower Austria. Radiocarbon, 50(1), 1-10.

Wild, E. M., Teschler-Nicola, M., Kutschera, W., Steier, P., Trinkaus, E., \& Wanek, W. (2005). Direct dating of early upper Palaeolithic human remains from Mladeč. Nature, 435(7040), 332-335. https://doi. org/10.1038/nature03585.

Zeeden, C., Kels, H., Hambach, U., Schulte, P., Protze, J., Eckmeier, E., et al. (2016a). Three climatic cycles recorded in a loess-palaeosol sequence at Semlac (Romania) - Implications for dust accumulation in South-Eastern Europe. Quaternary Science Reviews, 154, 130-142. https://doi.org/10.1016/j. quascirev.2016.11.002.

Zeeden, C., Kels, H., Hambach, U., Schulte, P., Protze, J., Eckmeier, E., et al. (2016b). Sedimentary data from the Semlac loess-paleosol sequence, supplement to: Zeeden, C., Kels, H., Hambach, U., Schulte, P., Protze, J., Eckmeier, E., et al. Three climatic cycles recorded in a loess-palaeosol sequence at Semlac (Romania) - implications for dust accumulation in south-eastern Europe. in prep. PANGAEA - Data Publisher for Earth \& Environmental Science. https://oi.org/10.1594/PANGAEA.859304.

Zilhão, J., \& d'Errico, F. (1999). The chronology and taphonomy of the earliest Aurignacian and its implications for the understanding of Neandertal extinction. Journal of World Prehistory, 13(1), 1-68. https://doi.org/10.1023/A:1022348410845.

Publisher's Note Springer Nature remains neutral with regard to jurisdictional claims in published maps and institutional affiliations.

\section{Affiliations}

\section{Wei Chu ${ }^{1}$ • L'ubomíra Kaminská ${ }^{2,3} \cdot$ Nicole Klasen $^{4} \cdot$ Christian Zeeden $^{5} \cdot$ György Lengyel $^{6}$}

1 Institute of Prehistoric Archeology, University of Cologne, Weyertal 125, 50923 Cologne, Germany

2 Department of History, Faculty of Arts, Pavol Jozef Šafárik University, Moyzesova 9, 04001 Košice, Slovak Republic

3 Institute of Archeology, Slovak Academy of Science, Hrnčiarska 13, 04001 Košice, Slovak Republic

4 Institute of Geography, University of Cologne, Albertus-Magnus-Platz, 50923 Cologne, Germany

5 Leibniz Institute for Applied Geophysics, Geozentrum Hannover, Stilleweg 2, 30655 Hannover, Germany

6 Department of Prehistory and Archaeology, University of Miskolc, 3515 Miskolc-Egyetemváros, Hungary 